\title{
Pohjoissaamen ja suomen kielen koloratiivikonstruktio vertailussa
}

\author{
MARJATTA JOMPPANEN \\ Giellagas-instituutti
}

Tiivistelmä. Tässä artikkelissa tarkastellaan pohjoissaamen ja suomen verbaalista koloratiivikonstruktiota rakenteen ja käytön kannalta. Suomessa koloratiivirakenne muodostetaan neutraalista perusinfinitiivistä (pääverbi) ja finiittimuotoisesta ekspressiiviverbistä (koloratiiviverbi), kun taas pohjoissaamessa koloratiivirakenteen molemmat osat ovat finiittimuotoisia verbejä. Koloratiiviverbin tehtävä on antaa jotain lisätietoa pääverbin merkitykseen, kuten selittää tekemisen tai olemisen tapaa, tempoa tai aspektia.

Suomessa koloratiivikonstruktion pääverbit ovat pääsääntöisesti kaksitavuisia perusverbejä; saamessa sitä vastoin pääverbit voivat olla kaksi- tai useampitavuisia perusverbejä tai johdoksia. Myös kielten koloratiiviverbit poikkeavat toisistaan. Suomessa ne ovat muodoltaan useampitavuisia, tavallisesti verbijohdoksia ja murteellisia verbejä, joiden merkitys selviää vain yhdessä pääverbin kanssa. Sen sijaan pohjoissaamen koloratiiviverbit ovat yhtä hyvin kaksi- tai useampitavuisia joko johdoksia tai perusverbejä. Ne ovat aivan tavallisia sanakirjasta löytyviä perusverbejä.

Tutkimukseni aineisto koostuu kaunokirjallisuudesta, joka on ilmestynyt kahdeksantoista vuoden aikana, vuosina 1979-1997. Se sisältää kummastakin kielestä 18 eri kirjoittajan tekstejä. Koska pohjoissaamen koloratiivikonstruktiosta ei ole aikaisemmin tehty laajempaa tutkimusta, tämän artikkelin pääpaino on saamen kielessä. 
Avainsanat: kontrastiivinen tutkimus; verbijohdos; koloratiivirakenne; ekspressiiviverbi; koloratiiviverbi; seriaaliverbi; suomi; pohjoissaame

\section{Johdanto}

Tarkastelen tässä artikkelissa pohjoissaamen ja suomen kielen verbaalista koloratiivikonstruktiota, lähinnä koloratiivirakenteen yhtäläisyyksiä ja eroja rakenteen ja käytön kannalta. Suomen (verbaalisessa) koloratiivikonstruktiossa ei-kuvaileva perusinfinitiivi (A-infinitiivi, ns. pääverbi) ja kuvaileva finiittimuotoinen verbi (ekspressiiviverbi, koloratiiviverbi) muodostavat liiton, esimerkiksi tyttö mennä kipitti. Pohjoissaamen vastaavassa rakenteessa verbiliitto muodostuu kahdesta finiittimuotoisesta verbistä nieida (s) bijadii (PAST.3SG) njaccuhii (PAST.3SG) 'tyttö mennä kipitti'. Verbaalista koloratiivikonstruktiota on tutkittu suomen kielessä lähinnä murteista ja tiettyjen kirjailijoiden teksteistä. Pohjoissaamen kielessä (tässä artikkelissa käytän synonyymisesti myös nimitystä saamen kieli) aiheesta ei ole tehty laajempaa tutkimusta.

Suomen tutkimusperinteessä koloratiivikonstruktion yhteydessä käytetään usein koloratiivikonstruktion jälkimmäisestä verbistä nimitystä deskriptiivi- tai ekspressiiviverbi (esim. Mikone 2002; Rääpysjärvi 2005; Hamunen 2007; Jarva 2008; Heikkinen \& Voutilainen 2009). Pohjoissaamesta ei ole tutkittu deskriptiivisiä verbejä, kuten verbien vartaloaineksen yhteyttä äänneasuun ilmaisemassa jotain tiettyä ilmiötä tai verbin ekspressiivistä merkitystä. Saamessa ei ole määritelty deskriptiivi- tai ekspressiiviverbejä. Nimitän koloratiivirakenteen ensimmäistä verbiä pääverbiksi, koska se ilmaisee sekä suomessa että saamessa millaisesta tekemisestä tai olemisesta on kysymys. Järjestyksessä toista verbiä nimitän koloratiiviverbiksi, joka värittää pääverbiä ja ilmaisee tarkemmin tekemisen tavan, tempon tai aspektin vetoamalla yleensä lukijan kuulo- tai näköhavaintoon. Saamen kieli on niin sanottu verbikeskeinen kieli ja suuri osa verbeistä välittää perusmerkityksen lisäksi myös muuta 
tietoa tekemisestä tai tekijästä. Esimerkiksi kun käännetään saameksi verbi juosta, pitää tietää, onko kyse kahdella jalalla juoksemisesta (ihmiset, linnut) vai muista kuin kaksijalkaisista juoksijoista. Kahdella jalalla juoksemista kuvaa verbi viehkat, ja muista kuin kaksijalkaisista käytetään verbiä ruohttat.

Tutkimukseni aineisto koostuu kaunokirjallisuudesta, joka on ilmestynyt kahdeksantoista vuoden aikana, vuosina 1979-1997 (liite 1 ja 2). Osa saamenkielisestä aineistosta on kirjoitettu jo vuosia aikaisemmin, mutta ilmestynyt vasta vuonna 1979 tai sen jälkeen. Kokosin ensin saamenkielisen tutkimusaineiston, jonka perusteella valitsin suomenkielisen aineiston. Kirjallisuutta on kummastakin kielestä mukana kahdeksaltatoista eri kirjoittajalta, yhteensä 4088 sivua. Kirjallisuudella tarkoitan tässä aikuisille suunnattuja romaaneja ja novellikokoelmia. Saamenkielisessä kirjallisuudessa muistelukset ovat tavallisia. Ne ovat kertomuksia, jotka ovat siirtyneet sukupolvelta toiselle. Muisteluksen kertoja on usein värittänyt muisteluksia omilla jutuillaan. Muistelukset erottuvat myös jossain tapauksessa kirjan nimestä, esimerkiksi Issá muitala 'Iisakki muistelee' tai Bás Galle ja eará muitalusat 'Pikku-Kalle ja muut muistelukset'. Yhdeltä kirjailijalta on tutkimusaineistossa mukana vain yksi kirja, koska kirjoittajan kirjoitustyylillä saattaa olla vaikutusta siihen, kuinka paljon hän käyttää koloratiivikonstruktioita. Siitä huolimatta, että kummastakin kielestä on laaja tutkimusaineisto (2 044 sivua), suomenkielisestä aineistosta löytyi kaksi ja saamenkielisestä aineistosta 11 koloratiivikonstruktion sisältävää lausetta. Sen vuoksi olen verrannut tässä artikkelissa suomen kielen aikaisempia tutkimuksia saamenkielisen tutkimusmateriaalini aineistoon.

Saamenkielistä kaunokirjallisuutta alkoi ilmestyä enemmän vasta vuoden 1979 jälkeen. Vuosi 1979 oli muutenkin saamen kielen kannalta tärkeä, koska silloin tehtiin päätös pohjoissaamen yhtenäisestä ortografiasta. Kolmas merkittävä asia samana vuonna oli Saamelaiskirjailijoiden yhdistyksen Sámi Girječálliid Searvvi (SGS) perustaminen. Pohjoissaame on yleisin saamen kielistä ja sitä puhutaan neljässä valtiossa, Suomessa, Norjassa, Ruotsissa ja jonkin verran myös Venäjän pohjois- 
osassa. Pohjoissaamen puhujia on noin 20000 (Saamelaiskäräjät). Kieltä voi hyvin nimittää Norjan, Ruotsin ja Suomen lingua francaksi, kieleksi, jota käytetään rajojen yli tapahtuvaan yhteydenpitoon.

\section{Koloratiivikonstruktion aikaisempi tutkimus}

\subsection{Suomen kielessä}

Koloratiivirakennetta esiintyy myös muissa lähisukukielissä. Pauli Saukkosen (1966) mukaan rakennetta käytetään kaikissa muissa itämerensuomalaisissa kielissä paitsi liivissä. Suomessa koloratiivikonstruktio esiintyy yleensä vain hämäläis-, lounais- ja savolaismurteissa. (Saukkonen 1966: 134.) Nimitys koloratiivinen konstruktio on Ahti Rytkösen lanseeraus. Hän ehdotti nimitystä Virittäjässä vuonna 1937 (s. 103-104). Koloratiivinen 'väritystä luova' oli tuolloin uusi nimitys deskriptiiviselle verbille. Oli tarve ottaa käyttöön uusi termi, koska deskriptiivinen ymmärrettiin tuolloin merkitykseltään verbiksi, joka kuvailee pelkästään ääntä, esimerkiksi tulla kolista tai mennä rytistä. Nykyään 'deskriptiivisellä on laajempi merkitys: se voi kuvata esimerkiksi liikkumistapaa tai näköhavaintoja, mutta siihen liittyy olennaisena elementtinä myös tunneaines (Mikone 2002: 129; Sivula 1989: 165).

Rytkösen mukaan koloratiivikonstruktiota on kahta päälajia: verbaalinen constructio colorativa verbalis ja nominaalinen constructio colorativa nominalis. Verbaalinen jakautuu vielä kahteen osaan: infinitivus cum verbo colorativo, joka on infiniittiverbin ja finiittiverbin liitto (puida pätkivät), ja verbum finitum cum verbo colorativo, joka muodostuu kahdesta finiittiverbistä (puivat pätkivät). Nominaalinen konstruktio jakautuu kahtia: genetivus cum nomine colorativo, jossa sanaliiton toinen jäsen on genetiivissä (kirveen kuokka), ja nominativus cum nomine colorativo, joka muistuttaa yhdyssanaa (kirveskuokka). Kirveen kuokka ja kirveskuokka tarkoittavat huonoa, tylsää kirvestä. (Rytkönen 1937: 103-104.) Setälän kieliopissa on maininta vain infinitivus cum verbo colorativo -tyyppisestä rakenteesta. I infinitiivi määritellään deskriptiiviverbin yhteydessä suhteen infinitiiviksi, esimerkiksi 
Hän juosta hölköttää tarkoittaa hölköttämistä juoksemisen suhteen. (Setälä 1987 [1880]: 40.) Iso suomen kielioppi pitää infinitivus cum verbo colorativo -tyyppistä rakennetta varsinaisena koloratiivirakenteena ja verbum finitum cum verbo colorativo -rakennetta edellisen varianttina. Kielioppi mainitsee rakenteen yhdessä muiden moniosaisten predikaattien kanssa. (ISK 2004: 443.) Penttilän mukaan koloratiivikonstruktio kuuluu rinnasteisten saneliittojen joukkoon muiden toistorakenteiden kanssa (Penttilä 2002: 564-566). Saamen tutkimuksen puolella Nielsen (1979 [1926-29]: 398 ja 405) näkee asian samansuuntaisena (ks. luku 2.2).

Aivan erityisen paljon koloratiivikonstruktiota on tutkittu eri kirjailijoiden teksteistä. Esimerkiksi F. E. Sillanpää, Joel Lehtonen, Veikko Huovinen, Anu Kaipainen, Väinö Linna, Kalle Päätalo ja Pentti Haanpää ovat käyttäneet rakennetta tyylikeinona (Iisa 1965; Havo 1966; Korhonen 1967; Sivula 1989: 168-175; Rääpysjärvi 2005; Gardemaister 2005). Uusin tutkimus on tehty Unto Ekin kirjoittamasta eräromaanista Hirventappopaikka (Heikkinen \& Voutilainen 2009: 135-169). Sivula (1989) arvelee, että jotkut kirjailijat käyttävät koloratiivirakennetta niin runsaasti, että he ovat ylittäneet normin ja koloratiivikonstruktiosta tehokeinona tulee kaavamainen. Normina hän pitää koloratiivirakenteen keskimääräistä esiintymistiheyttä tietyllä alueella. Itäsuomalaiset käyttävät puheessaan enemmän kuvailevaa sanastoa kuin länsisuomalaiset, mutta yksilölliset erot ovat suuret. (Sivula 1989: 171, 180-181.)

Koloratiivikonstruktion esiintymismäärää on myös tutkittu. Lauseopin arkiston materiaalin perusteella rakennetta esiintyy eniten pohjalais- ja savolaismurteissa, mutta se on niissäkin harvinainen. (Koistinen 2001: 103.) Tutkimuksen tulos poikkeaa Saukkosen selvityksestä, jonka mukaan koloratiivikonstruktiota esiintyy useimmiten savolaismurteiden lisäksi myös lounais- ja hämäläismurteissa (Saukkonen 1966: 134). Koska koloratiivikonstruktion käyttö liittyy vahvasti tiettyihin murteisiin, tutkimuksia on tehty myös tietyn murteen perusteella. Esimerkiksi Luttinen (2000) on kirjoittanut pro gradu -työnsä pohjoissavolaisista murteista. Koloratiivikonstruktion tutkimus on ollut erityisen suosittu 
opinnäytetöiden aihe (Iisa 1965; Havo 1966; Korhonen 1967; Luttinen 2000; Gardemeister 2005; Rääpysjärvi 2005; Hamunen 2007).

\subsection{Pohjoissaamessa}

Saamen koloratiivikonstruktiosta ei ole tehty niin systemaattisia tutkimuksia kuin suomen kielen osalta. Eri kirjoittajien kieliopeissa löytyy kuitenkin rakenteesta maininta. Nielsen (1979) lukee koloratiivikonstruktion asyndeettisten ilmaisujen ryhmään, jossa samaan tarkoitteeseen viittaavat sanat ovat peräkkäin eikä niiden välissä ole yhdistävää konjunktiota, kuten ovddos mayás 'edestakaisin', buriid baháid muosáhit 'maistaa hyvää ja pahaa' ja veallá duolbá 'makaa litteänä, čohkká steanžá 'istuu rötköttää litteänä’. (Nielsen 1979 [1926-29]: 398 ja 405.) Esimerkeissä on kyse nimenomaan saman rakenteen toistosta. Adverbit ovddos (nykyisen ortografian mukaan ovddas) 'eteenpäin' ja mayás 'jälkeensä, perälle, eteenpäin (ajallisesti)' kuuluvat kielihistoriallisesti alkujaan paikallissijaisiin translatiiveihin, joista ovat kehittyneet pohjoissaamen suuntaa ilmaisevat $s$-päätteiset adverbit, kuten davás 'pohjoiseen' (Sammallahti 1998: 70). Ilmaisussa buriid baháid muosáhit 'maistaa hyvää ja pahaa’ on taas kyse siitä, että verbin muosáhit valenssiin kuuluu akkusatiivisijainen täydennys, jota edustavat kaksi monikon akkusatiivissa olevaa adjektiivia buriid ja baháid. Koloratiivikonstruktiota edustavat puolestaan Nielsenin esimerkit veallá duolbá 'makaa litteänä, čohkká steanžá 'istuu rötköttää litteänä, joissa kaksi finiittiverbiä kuvailee samaa subjektitarkoitetta. Rakenteen ensimmäinen verbi kuvaa olemisen tapaa ('maata, istua'), jota toinen verbi tarkentaa ('makaa litteänä, rötköttää litteänä).

Knut Bergsland (1961: 100) ja Klaus Peter Nickel (1994: 399) mainitsevat kieliopeissaan verbiliiton (koloratiivikonstruktion), jossa predikaatti muodostuu useammasta perättäisestä verbistä. Ne kongruoivat subjektin kanssa ja niiden välissä ei ole konjunktiota. Jälkimmäinen verbeistä kuvailee tarkemmin ensimmäisen verbin ilmaisemaa tekemistä tai olemisen laatua, esimerkiksi maid don čálát ruccistat? 'Mitä sinä kirjoittaa räpellät?’. Bergsland (1961: 100) lisää vielä edelliseen, että 
vastaavanlainen kahden verbin yhdistelmä voi esiintyä myös potentiaalisessa lauseenvastikkeessa, eležat jámežat 'elänet tai kuollet' ('joko elät tai sitten kuolet').

Pekka Sammallahti (2000) nimittää koloratiivirakenteen ensimmäistä verbiä verbin attribuutiksi (suomen kielen tutkimuksessa 'määrite') ja toista verbiä pääsanaksi. Máhtte vuodjá čeasaha 'Matti ajaa kaahaa', vuodjá on määrite ja čeasaha edellisen verbin pääsana. Määritteen ja pääsanan välillä on kongruenssi, joten verbin määrite on aina samassa muodossa kuin pääsana, esimerkiksi aktion essiivi Maid dii lehpet čállime ruccisteame 'Mitä te olette kirjoittaa räpeltämässä?', (čállime ja ruccisteame vastaavat muodoltaan suomen MA-infinitiivin inessiiviä) (Sammallahti 2000: 79). Sammallahden nimittämää määrite-pääsanajakoa on ajateltu suomen kielen tutkimuksessa yleensä toisin päin: nimenomaan koloratiivirakenteen ensimmäistä verbiä on nimitetty pääverbiksi (esim. Luttinen 2000; Mikone 2002: 29). Edellisestä näkemyksestä poikkeaa kuitenkin Iso suomen kielioppi, joka nimittää verbiparin järjestyksessä toista verbiä deskriptiiviseksi pääverbiksi (ISK 2004: 443). Tässä artikkelissa käytän pääverbi-nimitystä verbiparin ensimmäisestä osasta. Nimitys perustuu enemmän koloratiivirakenteen semanttiseen tulkintaan kummassakin kielessä kuin syntaktiseen tulkintaan. Suomen kielessä vain verbiparin jälkimmäinen osa on finiittimuotoinen verbi ja siitä syystä pääverbi.

Pohjoissaamen aikaisemmassa tutkimuksessa tavataan ainoastaan koloratiivikonstruktiota, jossa rakenteen kummatkin verbit ovat morfologisesti samassa muodossa; kyseessä on siis verbum finitum cum verbo colorativo -tyyppinen rakenne, jossa molemmat verbit kongruoivat subjektin kanssa. Voin siten vastata Hamusen kysymykseen, onko saamessa finiittisten verbiparien lisäksi "kunnollista koloratiivirakennetta" (Hamunen 2007: 61), että näyttää siltä, että ainakin pohjoissaamessa esiintyy vain koloratiivikonstruktiota, jossa rakenteen ensimmäinen ja toinen verbi ovat muodoltaan identtiset.

On huomionarvoista, että pohjoissaamen ja suomen koloratiivikonstruktion käsitteet eivät vastaa täysin toisiaan. Saamessa voitaisiin käyttää 
toistorakenteen tai asyndeettisten ilmaisujen nimitystä, koska verbiparin molemmat verbit ovat finiittimuodossa ja syntaktisesti tasavertaisia keskenään. Suomen koloratiivirakenteessa on kyse lähinnä määriteosan (infinitiivi) ja semanttisen täydennyksen (finiittiverbi) yhdistelmästä. Kuitenkin sekä saamen että suomen kielessä verbiparin keskinäinen järjestys on samansuuntainen: koloratiiviverbiä edeltää neutraalimpi pääverbi, joka kuvaa tekemisen tai olemisen perusluonnetta.

\section{Koloratiivikonstruktion pääverbi}

Koloratiivikonstruktio on rakenne, joka muodostetaan kahdesta verbistä, pääverbistä ja koloratiiviverbistä, joilla on sama subjektitarkoite. Suomen tutkimusperinteessä näitä kahta verbiryhmää on usein tarkasteltu erikseen, joten jatkan tässä artikkelissa samaa jaottelua ja aloitan tarkastelun pääverbistä. Koloratiivikonstruktion pääverbin luokittelun perustana käytän verbin muototyyppiä ja verbin merkitystä sekä käyttöä.

Suomen kielen koloratiivikonstruktiossa ovat tavallisia kaksitavuiset ja $e$-vartaloiset verbit, kuten juosta, mennä, tulla (Luttinen 2000: 9-11; Hamunen 2007: 44-45; Heikkinen \& Voutilainen 2009: 156). Lisäksi suomen pääverbit näyttävät olevan yleensä johtamattomassa muodossa, kuten ajaa, itkeä, sanoa. Saamenkielisessä aineistossani ei erotu yhtään verbiä tai verbiryhmää, joka esiintyisi useammin kuin muut ja olisi jotenkin tyypillinen koloratiivirakenteelle. Sen sijaan pääverbit voivat olla verbijohdoksia tai aivan yhtä hyvin verbin johtamattomia muotoja. Aineistossani noin puolet pääverbeistä on perusverbejä, kuten geahččat 'katsoa', čaibmat 'nauraa', gaikut 'vetää, goargyut 'sauvoa', veallát 'maata', hállat 'puhua', ja puolet verbijohdoksia. Ei voi nimetä jotain tiettyä pääverbijohdostyyppiä vaan johdoksia on useita erilaisia: subitiiviverbi (čálistit < čállit 'kirjoittaa nopeasti'), subitiivi-deminutiiviverbi (vázzilit < vázzit 'kävellä lyhyt matka'), inkoatiiviverbi (suhkalit < suhkat 'lähteä soutamaan') ja kontinuatiiviverbi (gorkyodit < goargyut 'sauvoa (ylävirtaan) hitaasti'), hoigadit (< hoigat) 'sauvoa (alavirtaan) hitaasti'. 
Pääverbin ilmaisema toiminta tai tila on sekä suomen että saamen koloratiivirakenteessa konkreettista ja aistein havaittavaa. Yleensä suomen kielessä pääverbi kuvaa joko liikkumista (ajaa, mennä, juosta, kävellä), muuta toimintaa (sanoa, itkeä, lypsää) tai olemista (olla, seistä, maata) (Luttinen 2000: 12-14; Hamunen 2007: 44-45; Heikkinen \& Voutilainen 2009: 156). Vastaavasti myös saamenkielisessä aineistossa pääverbi kuvaa liikkumista (vázzilit 'kävellä lyhyt matka nopeasti', goarknut 'sauvoa (ylävirtaan)', suhkalit 'lähteä soutamaan'), muuta toimintaa (čaibmat 'nauraa', hállat 'puhua', geahččat 'katsoa') ja olemista (veallát 'maata'). Luttisen havainnon mukaan suomen pääverbien joukossa ei esiinny kuitenkaan nykyajan elämänmenoon liittyviä verbejä, kuten kirjoittaa, piirtää ja kuvata. (Luttinen 2000: 14-15.) Saamen kielen koloratiivirakenteessa sen sijaan verbi ćállit 'kirjoittaa' on aivan tavallinen, esimerkiksi Maid don čálát ruccistat? 'Mitä sinä kirjoittaa töherrät?' (Nielsen 1979 [1926-29]: 405), Maid don čálát ruzat? 'Mitä sinä kirjoittaa töherrät?' (Nickel 1994: 399). Kirjoittamista merkitsevä verbi esiintyy myös tutkimusaineistossani subitiiviverbijohdoksena (1) čálistit 'kirjoittaa nopeasti'.

(1) Áiggui (PAST.3SG) juoidá ćálistit (INF) ruzistit (INF) (Einejord 1986: 54). 'Aikoi jotain kirjoittaa töhertää'

Esimerkkilauseessa (1) pääverbi täydentää apuverbiä áigut 'aikoa', toisin sanoen lause on merkitykseltään futuurinen. Tavallisesti saamen, kuten myös suomen, kielen koloratiivikonstruktiota käytetään viittaamaan menneeseen tai tapahtumassa olevaan tekemiseen tai olemiseen. En löytänyt suomen kielen aikaisemmista tutkimuksista pohdintoja ja esimerkkejä koloratiivikonstruktion käytöstä apuverbin täydennyksenä futuurisessa merkityksessä, toisen verbin täydennyksenä kyllä, pääseepähän ukko ajaa röhöttelemään (Rääpysjärvi 2005: 33). 


\section{Koloratiivirakenteen koloratiiviverbi}

Suomen koloratiivikonstruktion koloratiiviverbi on tyypillisesti kolmitai useampitavuinen verbi (Heikkinen \& Voutilainen 2009: 156, 158; Jarva 2008: 16; Hamunen 2007: 20-22; Jarva \& Kytölä 2007: 258-264; Rääpysjärvi 2005). Luttisen aineistossa $A$-vartaloiset verbit ovat useimmin esiintyviä, kuten humputtaa, kouhottaa, liputtaa, töllöttää, pöllyyttää (Luttinen 2000: 30-35). Pyrkimys kolmitavuiseen koloratiiviverbiin on niin kova, että puhuja muuntaa kaksitavuisen koloratiiviverbin kolmitavuiseksi käyttämällä verbin passiivimuotoa tai kolmannen infinitiivin illatiivia kävelläl lompsimmaan tai supiinia sannoov veäntännä (Luttinen 2000: 37 ja 84-85). Saamenkielisen aineiston perusteella ei ole nähtävissä tendenssiä kolmi- tai useampitavuisten koloratiiviverbien suosintaan. Kaksitavuisia koloratiiviverbejä on saman verran kuin kolmitavuisiakin, esimerkiksi kaksitavuisia verbejä ovat stuhčat 'loiskia', ruohčat 'rytistä', skoalkit 'kolista', gurgát 'lojua maata pitkin pituuttaan', spinjut 'kimittää' ja kolmitavuisia verbejä ruccistit 'töhertää', susttašit 'nuuhkia', njilistit 'hihittää, guvrulit 'kyyristellä, šavahit 'kohista, kaahata'. Saamenkielisessä aineistossa yksikään tietty verbiryhmä ei esiinny useammin kuin muut, joten prototyyppistä koloratiiviverbiä ei voi nimetä.

Suomen ja saamen koloratiiviverbit eroavat toisistaan myös muutoin kuin morfologisesti. Silmiinpistävin ero on suomen koloratiiviverbien murteellisuus: koloratiivikonstruktioissa viihtyvät esimerkiksi verbit nytyttää, humpuuttaa, hurauttaa, jaurauttaa. Verbien merkitystä on usein vaikea ymmärtää ilman pääverbiä (myös Jarva \& Kytölä 20: 258). Esimerkiksi suomenkielisessä aineistossani on koloratiiviverbi huhtoa (2), jonka merkitys jää murretta taitamattomalle hämäräksi ilman pääverbiä siivota. Sen sijaan saamen koloratiiviverbit ovat ilman lausekontekstiakin ymmärrettäviä verbejä. Saamen kielen pääverbit ja koloratiiviverbit ovat yhtä kirjakielisiä, jos kriteerinä pidetään sitä, että ne löytyvät pohjoissaamen sanakirjoista (esim. Sammallahti 1989 ja 1993; Vest 1995). Joissakin tapauksessa myös suomen koloratiiviverbit ovat yleiskielisiä perusverbejä, jotka kuitenkin koloratiivirakenteen osana 
saavat perusmerkityksestään poikkeavan merkityksen, esim. ampua poksauttaa, katsoa napittaa (Heikkinen \& Voutilainen 2009: 137). Suomen koloratiivikonstruktion tutkimuksessa käytetään termejä deskriptiivi-, ekpressiivi- ja onomatopoeettinen verbi. Näitä nimityksiä ei voi ohittaa tässäkään artikkelissa, vaikka ne eivät ole oleellisia pohjoissaamen koloratiiviverbin kuvauksen kannalta.

(2) Tuohon lattialle se kuoli ja minä... minä vaan siivota (INF) huhdoin (PAST.1SG) niitä jälkiä (Joenpolvi 1988: 84).

Suomen koloratiivirakennetta kuvataan tyypillisesti esim. seuraavasti. Koloratiivirakenteessa käytetään deskriptiiviverbejä erilaisten äänten kuvailussa, nauraa räkättää. Yleistä on myös liikkeen tai kulkemisen tavan kuvaus, mennä taapersi, ja niihin liittyvien äänien kuvailu deskriptiiviverbillä, mennä kolisti. (Sivula 1989: 168-170.) Deskriptiivinen on merkitykseltään kuvaileva, esittävä tai kertova, ja se tuntuu kuultuna samalta, mitä se merkitsee (SSS 2000 s.v. deskriptiivinen). Deskriptiivinen verbi kuvailee äänneasullaan tekemistä (USS 1990 s.v. ja MOT 2.0 s.v. deskriptiivinen verbi). Deskriptiiviverbi voi olla luonteeltaan onomatopoeettinen, ääntä jäljittelevä, kuten kukkua, kohista (MOT 2.0 s.v. onomatopoeettinen).

Mikosen (2002) mukaan deskriptiiviverbi kuvaa myös ilman koloratiivirakenteen ensimmäistä verbiä tarkoitetta, johon se viittaa. Kun rakenteen molemmat verbit kuvaavat samaa tarkoitetta, kuvailun merkitys korostuu toiston avulla. (Mikone 2002: 29.) Toisaalta samalla koloratiiviverbillä voi olla kaksi eri merkitystä, kuten nostaa kihauttaa ('nostaa ylöspäin'), nauraa kihauttaa ('kuulua kihahtava ääni'), lisäksi kihauttaaverbi sisältää merkityksen 'tehdä nopeasti' (Rääpysjärvi 2005: 47-48; Jarva 2008: 18-19). Koloratiiviverbi on usein niin vahvasti murteellinen, että yleiskielinen merkitys selviää vain pääverbin merkityksen perusteella (myös Hamunen 2007: 18), joten sitä ei voi mielestäni luokitella toistorakenteeksi.

Deskriptiivisiä sanoja on määritelty myös muodon perusteella motivoituneiksi. Esimerkiksi Jarva (2008) ja Luttinen (2002) ovat tarkastel- 
leet ekspressiivisten sanojen (deskriptiiviset ja onomatopoeettiset sanat) ensimmäisen tavun vokaalivaihtelua, kuten halkutella, helkytellä, hulkutella (Jarva 2008: 21-23; Luttinen 2002: 25-27). Edellisen lisäksi Jarva on tutkinut myös konsonanttivaihtelua 1. ja 2. tavun rajalla, esim. kahottaa, kahjottaa (Jarva (2008: 21-23). Mikosen mielestä deskriptiivisten sanojen määritteleminen muodoltaan motivoituneiksi on harhaanjohtavaa, koska ei ole selvitetty esim. sitä, mitä tarkoittaa muodon motivoituneisuus (Mikone 2002: 29). Pohjoissaamessa ei ole tehty vastaavanlaisia tutkimuksia, joissa sanoja olisi luokiteltu esim. tietyn tavun vokaalivaihtelun perusteella.

Suomen koloratiiviverbi on useimmiten ekspressiiviverbi, joka voi olla sen lisäksi johdos sisältäen esim. kausatiivisen, frekventatiivisen tai momentaanisen lisämerkityksen (Luttinen 2000: 10-11; Rääpysjärvi 2005: 53; Heikkinen \& Voutilainen 2009: 156-158). Saamen kielessä verbin ekspressiivisyys on olemassa jo verbin perusmerkityksessä tai se saadaan aikaan johtimen lisäämisellä. Esimerkiksi perusverbit boaggut 'köpötellä vääräsäärisenä, bircut 'kävellä tepsuttaa jalan syrjällä astuen' ja skužžat 'kävellä edestakaisin levottomana'. Viimeksi mainittu verbi antaa lisätietoa paitsi liikkumistyylistä myös liikkujan mielentilasta. Saamen kielen verbien kausatiivi-, frekventatiivi-kontinuatiivi-, deminutiivi- ja momentaanijohdokset ovat erityisen produktiivisia ja joissakin tapauksissa jopa pakollisia (Sammallahti 1998: 88). Esimerkiksi johdokset boaggut-verbistä, jonka perusmerkitys on köpötellä, kävellä väärä-, länkisäärisenä: boakkuhit 'panna köpöttelemään' on kausatiivijohdos ja boakkostit 'kulkea vääräsäärisenä vähän matkaa tai lyhyen aikaa' on deminutiivi-subitiivijohdos.

\section{Pääverbin ja koloratiiviverbin liitto}

Olen edellä tarkastellut suomen ja saamen koloratiivikonstruktiossa esiintyviä verbityyppejä erikseen. Koloratiivirakenteen verbit kuvaavat nimenomaan yhdessä jotain tiettyä tapahtumaa. Ensimmäinen verbi ilmaisee tekemisen tai olemisen perusluonteen ja koloratiiviverbi antaa 
jotain lisätietoa ensimmäisen verbiin liittyen. Suomen kielessä molemmat koloratiivirakenteen verbit ovat lauseen ymmärtämisen kannalta tarpeet, esim. He katsoa napittivat; ${ }^{\star}$ he napittivat (Heikkinen \& Voutilainen 2009: 137). Koloratiiviverbin merkitys yhdessä pääverbin kanssa poikkeaa sen perusmerkityksestä. Suomen kielessä koloratiivikonstruktiota on nimitetty myös kiteytyneeksi verbiliitoksi, kivettyneeksi rakenteeksi, jota ei voi johtaa produktiivisesti syntaktisilla säännöillä (Hakulinen \& Karlsson 1979: 234-235.) Ojutkangas (1998) nimittää koloratiivirakennetta seriaaliverbimäiseksi rakenteeksi, koska seriaaliverbirakenteen perustapauksessa yksi tapahtuma ilmaistaan kahden tai useamman verbin avulla. Ojutkankaan luokituksen mukaan on enemmän tai vähemmän seriaaliverbimäisiä rakenteita. Kaikkein seriaaliverbimäisin on rakenne, jossa verbiparin kummatkin jäsenet ovat merkitykseltään yhtä painavia ja samassa taivutusmuodossa (Ojutkangas 1998: 110 ja 115117.) Saamen koloratiivikonstruktio on seriaaliverbimäinen rakenne, koska saamessa verbiparin kummatkin verbit ovat finiittimuodossa ja tapahtuman kuvaamisen kannalta tarkasteltuna yhtä tärkeitä, myös syntaktisesti tasavertaisia. Esimerkkilauseessa (3) koloratiiviverbi gurgát 'maata pitkin pituuttaan' on lausekontekstin kannalta yhtä painava viesti lukijalle kuin pääverbi veallát 'maata jonossa'.

(3) O, o-ho go oppa fállat veallajit (PRES.3PL) gurgajit [sic] (PRES.3PL) miehta gárcu (Hans Aslak Guttorm 1982: 29). 'O, o-ho kun valaatkin makaavat jonossa pitkin pituuttaan pitkin karikkoa.'

\subsection{Koloratiivirakenteen verbit morfologisessa tarkastelussa}

Muodon kannalta tarkasteltuna suomen ja saamen koloratiivikonstruktion verbit ovat toisistaan hyvinkin poikkeavat. Suomen kielessä pääverbi on tavumäärältään lyhempi kuin koloratiiviverbi, usein siitä syystä, että edellinen on perusverbi ja jälkimmäinen on johdos (myös Heikkinen \& Voutilainen 29: 15, 158; Luttinen 2000: liite 5). Suomen koloratiivikonstruktio muodostuu verbiparista; ensimmäinen on määriteosa, johtamaton perusmuoto (infinitiivi), jota syntaktinen pääverbi (finiittinen 
muoto) seamanttisesti täydentää. Esimerkiksi lauseessa (4) on kaksitavuinen pääverbi nauraa ja nelitavuinen verbijohdos lauleskella. Saamen kielessä ei voi havaita samansuuntaista ilmiötä kuin suomessa. Esimerkiksi lauseessa (5) sekä pääverbi että koloratiiviverbi ovat kaksitavuisia verbejä. Saamessa pääverbi voi olla tavumäärältään jopa pitempi kuin koloratiiviverbi; esimerkissä (6) pääverbi on kolmitavuinen ja koloratiiviverbi kaksitavuinen.

(4) Portilla seisoi emännöitsijä sinisessä tyykipuvussa ja nauraa (INF) lauleskeli (PAST.1SG) koiralle niin kuin ei olisi muuta nähnytkään: pidä puoles vaan pidä, älä päästä sitä rumilusta kotios. (Salama 1978: 16.)

(5) Bikka čaimmadii (PAST.3SG) ja hálai (PAST.3SG) spinjui (PAST.3SG): - Mun dat ieš gáttan, ahte dál jo farga dálva. (Hans Aslak Guttorm 1982: 57.) 'Bikka nauroi ja puhua kimitti: - Kyllä minä itsekin luulen niin, että jo pian tulee talvi.'

(6) Son joavddai, gorkyodii (PAST.3SG) stužai (PAST.3SG) čuimmiinis šierresjoga njálbmai (Hans Aslak Guttorm 1982: 7). 'Hän pääsi perille, sauvoa loiski (ylävirtaan) sauvoineen Šierresjoen suulle’'

Kun tarkastelee saamen pääverbiä ja koloratiiviverbiä yhdessä morfologian näkökulmasta, on huomionarvoista, että verbit ovat usein taivutustyypiltään yhteneväiset, kuten esimerkkilauseissa (3) veall-át gurg-át 'maata jonossa pitkin pituuttaan' ja (7) hoig-at šávv-at 'sauvoa kohista'. Jos perusverbit eivät ole taivutustyypiltään samanlaiset ( guvr-ut, vázz-it), sitä voivat olla sen sijaan verbijohdokset; esimerkiksi lauseessa (8) vázzilit guvru-lit 'lähteä kävelemään kyyristellen', vázzi-lit on perusverbistä vázzit 'kävellä' ja guvru-lit perusverbistä guvrut 'kävellä selkä köyryssä. Aivan vastaavasti on lauseessa (1) čáli-stit ruzi-stit 'kirjoittaa (nopeasti) töhertää.

(7) Nu si hoigadedje (PAST.3PL) šávahedje (PAST.3PL) Lásseš lusa (Hans Aslak Guttorm 1982: 29). 'Niin he sauvoa kohistivat pikku Lassen luokse.'

(8) Nu son vázzilii (PAST.3SG) guvrulii (PAST.3SG) ja guovllai gárgui, bisanii, dohppii geadggi ja fas luoitilii, dohppii nuppi ja goalmmada (Hans 
Aslak Guttorm 1982: 8). 'Niin hän kävellä (lyhyen matkaa) kyyristeli ja tihrusteli karikkoa, pysähtyi, tarrasi kiveen ja taas päästi, tarrasi toiseen ja kolmanteen.'

Pääverbin ja koloratiiviverbin yhteneväisen taivutustyypin lisäksi näyttää siltä, että sekä pääverbi että koloratiiviverbi ovat myös merkitykseltään yhteneväisiä verbijohdoksia. Esimerkkilauseessa (9) sekä pääverbi että koloratiiviverbi ovat inkoatiiviverbejä, jotka ilmaisevat jonkin aloittamista tai alkamista suhkalit jullagoahtit 'lähteä soutamaan, alkaa mekastaa'. Aivan vastaavasti lauseen (1) molemmat koloratiiviverbit ovat subitiiviverbejä (čálistit ruzistit 'kirjoittaa töhertää') ja ilmaisevat kyseessä olevan nopean ja lyhytkestoisen tekemisen.

(9) Bikka suhkalii (PAST.3SG) jullagodii (PAST.3SG) (Hans Aslak Guttorm 1982: 58). 'Bikka alkoi soutaa rytistellä.'

\subsection{Koloratiivirakenteen verbien käyttö}

Koloratiivikonstruktion käyttö suomessa ja saamessa on samantapaista. Suomen kielen koloratiivikonstruktio kuvaa useimmiten subjektitarkoitteen tekemistä tai olemista (Heikkinen \& Voutilainen 2009: 153-154; Hamunen 20027: 23). Aivan samoin saamessa koloratiivikonstruktio kuvaa tekemisen tai liikkumisen ja olemisen tapaa ja tempoa. Huomionarvoista on, että pääverbin kuvaillessa ihmisen liikkumista koloratiiviverbi selittää liikkumisesta johtuvaa ääntä ikään kuin se olisi luonnon aiheuttamaa. Esimerkiksi ruohčat 'ryskyä, rytistä, rätistä, päristä' (10); jiekya ruohčá 'jää rytisee’, skoalkit 'kolista, kopista, kopsata' (11); biegga skoalká nurkkiin 'tuuli kolisee nurkissa (talon ulkopuolella)', šávvat 'kohista, pauhata, ryöpytä (jhkn), tulvia (jhkn joukkona)' (7); guoika šávvá 'koski kohisee’, jullat ‘jylistä, kolista, mekastaa’ (9); bajándálki jullá 'ukkonen jylisee', stuhčat 'liplattaa loiskia' (6); bárru stuhčá 'aalto loiskii' (Vest 1995: 139-140). Kuten esimerkkilauseista (6, 7, 9, 10, 11) voi havaita, luonnonääniä kuvailevilla verbeillä voi värittää myös ihmisen liikkumisesta aiheutuvaa ääntä. Luonnonääniä kuvaava verbi ei yksis- 
tään kerro lukijalle subjektitarkoitteen tekemisestä vaan myös pääverbi on välttämätön. Esimerkkilauseissa kaikki koloratiiviverbit liittyvät pääverbiin, joka kuvaa kontekstissaan vedessä liikkumista: gorkøodit 'sauvoskella (ylävirtaan)', goargyut sauvoa (ylävirtaan), gaikut 'kiskoa, vetää, hoigat 'lykkiä, sauvoa (alavirtaan)', suhkalit 'alkaa soutaa'. Kaikki edellä esitetyt lauseet ovat samalta kirjoittajalta. Kuitenkaan Hans Aslak Guttormin (1982) romaanin ja Unto Ekin kirjoittaman eräromaanin välillä ei ole havaittavissa yhtymäkohtia koloratiivikonstruktion käytössä (Heikkinen \& Voutilainen 2009), siitä huolimatta että molemmissa romaaneissa luonnonkuvaus on tärkeässä osassa.

(10) Juoksa váccii gárgo miel', jurai rohtorádjai, gaikkui (PAST.3SG) ruožai (PAST.3SG) ja smiezai áiggiid, viimmat luovvanii ruotkkus, gesii vatnas lusa (Hans Aslak Guttorm 1982: 9). 'Juoksa käveli karikkoa pitkin, jyristeli ryteikköön, veti rytisteli ja mietti hetken, viimein irtosi juurakosta, veti veneen luoksensa.

(11) Goarkyui (PAST.3SG) skolkkii (PAST.3SG) njavis njavvai, guovllai duoppa dáppa beale vatnas bodnai ja okto háleštii Ámmonis (Hans Aslak Guttorm 1982: 16). 'Sauvoi kaahasi kolisteli nivalta toiselle, vilkaisi vuoroin kummaltakin puolelta venettä joen pohjaan ja jutteli itsekseen Amundista'

Koloratiiviverbillä ilmaistaan myös ihmisestä itsestään johtuvaa ääntä. Suomen ja saamen koloratiivikonstruktiolla kuvaillaan esim. nauramisen tapaa siten, että pääverbiin nauraa/čaibmat liitetään koloratiiviverbi. Kokkonen (2009) on tutkinut kyselytutkimuksen avulla suomen kielen nauramista kuvaavia verbejä muun muassa koloratiivirakenteessa. Hän on ottanut huomioon myös vastaajien iän ja sukupuolen. Tuloksena on tieto siitä, että verbit röhöttää, hekottaa, hohottaa, räkättää ja hykertää ovat luontevia nimenomaan koloratiivirakenteessa, mutta verbit hihittää, käkättää ja tirskua eivät vastaajien mielestä siihen kuulu. Sukupolvien välinen ero tulee esille siinä, että nuoret vastaajat pitävät verbiä hohottaa (nauraa hohottaa) ja aikuiset vastaajat verbiä räkättää (nauraa räkättää) luonnollisempana koloratiivirakenteessa. (Kokkonen 2009: 14.) Suomessa koloratiivikonstruktiota on pidetty leimallisena 
nimenomaan vanhemman sukupolven käytössä (Heikkinen \& Voutilainen 2009: 138; 69-76). Sukupolvien välisiä eroja ei ole tutkittu saamen kielessä.

\subsubsection{Pohjoissaamen koloratiivikonstruktio toistorakenteena}

Pohjoissaamen koloratiivikonstruktiota voi kuvailla käytöltään toistorakenteeksi. Esimerkiksi verrattaessa suomen että saamen nauraa/ čaibmat-pääverbin käyttöä koloratiivirakenteessa, suomen koloratiiviverbin merkityksen voi ymmärtää vain yhdessä pääverbin kanssa. Lauseessa (4) koloratiivikonstruktio muodostuu verbeistä nauraa lauleskeli. Verbi lauleskella ei yksinään kerro siitä, että on kyse 'nauramisesta'. Saamenkielisessä esimerkissä (12) sen sijaan verbin nihlistit merkitys on 'hihittää, joka jo yksistään ilmaisee, että on kyse nauramisesta. Aivan vastaavanlainen tapaus on esimerkissä (5), hálai spinjui 'puhua kimitti', jossa verbi spitnjut 'kimittää' kertoo merkityksestä 'korkealla äänellä puhuminen'. Esimerkissä (5) ja (12) on siis kyse toistorakenteesta, koska lauseiden koloratiiviverbit ilmaisevat jo yksin merkityksen. Kummassakin tapauksessa koloratiiviverbin voi jättää lauseesta pois ja lause säilyy syntaktisesti kieliopillisena, Bikka čaimmadii ja spinjui 'Bikka nauroi ja kimitti' ja Biret njilistii ja de skeaikkihii 'Biret hihitti ja sitten nauraa räkätti'. Semanttisesti kummastakin lauseesta tulisi kuitenkin vajavainen ilman pääverbiä. Lauseessa (12) verbi čaibmat toimii sekä verbien njilisit ja skeaikkihit pääverbinä; skeaikkihit-verbi voi tarkoittaa myös riekon räkätystä. Lauseessa (5) on rinnastettu toiminnot 'nauraminen ja puhuminen’; jos pääverbi hállat jätetään pois, lukija voisi ymmärtää merkityksen väärin 'nauraa kimitti' (čaimmadii spinjui). Myös tämä tulkinta olisi semanttisesti aivan mahdollinen.

(12) Biret čaimmai (PAST.3SG) njilistii (PAST.3SG) ja de skeaikkihii (Paltto 1989: 61). 'Biret nauroi hihitti ja sitten nauraa räkätti.'

Saamen koloratiivikonstruktio on asyndeettinen ilmaisu, jossa verbiparin molemmat jäsenet ovat syntaktisesti tasavertaiset ja semanttisesti 
yhtä tarpeelliset, kuten edellä tuli jo esille. Verbien keskinäinen järjestys on muuttumaton, pääverbin jälkeen tulee koloratiiviverbi. Pohjoissaamen koloratiivikonstruktiota voi perustellusti nimittää toistorakenteeksi myös siitä syystä, että verbiparin molemmat jäsenet ovat usein taivutustypiltään samanlaiset verbijohdokset.

\subsubsection{Koloratiivikonstruktio aspektin kuvauksessa}

Koloratiivirakenteella on monta samanaikaista funktiota. Sitä käytetään toiston ja laadun lisäksi aspektin kuvauksessa sekä suomessa (Luttinen 2000: 40 ja 84; Rääpysjärvi 2005: 40-41) että saamessa. Rakenteella kuvataan tekijän otetta tekemiseen, reippautta tai hitautta. Esimerkissä (3) pääverbiin veallát '(eläimestä) maata kyljellään' liittyy koloratiiviverbi gurgát 'olla jonossa, lojua, maata pitkin pituuttaan'. Kyse on siinä mielessä toistorakenteesta, että kummankin verbin merkitykseen sisältyy 'makaaminen'. Pääverbi kertoo, että on kyse eläimestä ja makaamisen asennosta, kun taas koloratiiviverbi tarkentaa yksilön suhdetta muihin ('maata jonossa') ja aspektia ('lojua'), jolloin kyse on pitkäkestoisesta toiminnasta. Jos jättää pois toisen verbeistä, lause säilyy aivan ymmärrettävänä mutta on epätarkempi kuvaus olemisen tavasta.

Lauseessa (13) implikoidaan sisäistä pakkoa toimia tietyllä tavalla ferte vuos geahččat susttašit 'pitää ensin katsoa nuuskia hitaasti'. Verbin susttašit merkitykseen sisältyy tieto nuuskimisen temposta, joka on hidas. Neutraalia nuuskimista kuvataan verbillä snuggat $\sim$ snuoggat. Kuten jo edellä tuli esille, saamessa myös pääverbi voi olla johdos ja ilmaista tekemisen tempoa, kuten esimerkissä (8). Pääverbi vázzilit ilmaisee, että kyse voi olla kävelemään lähtemisestä ja siitä, että kävelee vain lyhyen matkan tai käy jossakin kävellen. Lauseen (8) loppupuolella on tarkennus kävelemisen tavasta; menijä kävelee vähän väliä pysähdellen. Koloratiiviverbi guvrulit ilmaisee kävelemisen tavan: 'kyyristellen'. Esimerkkilauseen (1) pääverbi ćálistit 'kirjoittaa vähän ja nopeasti' (johdos verbistä čállit) ilmaisee sekä tavan että tempon ja koloratiiviverbi ruzistit (ruccistit) tarkentaa tekemisen laatua 'töhertää. 
(13) Orru leamen nu njálgga, ahte ferte vuos geahččat (INF) susttašit (INF)... dan oktii go beassa smáhket basistuvvon erttetsárgá (Eino Guttorm 1985:11). 'Näyttää olevan niin herkullinen, että pitää ensin katsoa nuuskia hitaasti... kun kerrankin pääsee maistamaan paahtunutta kylkeä'.

\section{Lopputulema}

Artikkelissa kartoitettiin verbaalisen koloratiivikonstruktion käyttöä pohjoissaamen ja suomen kielessä, lähinnä rakenteen yhtäläisyyksiä ja eroja rakenteen käytön kannalta. Suomen koloratiivikonstruktiossa ei-kuvaileva perusinfinitiivi ja kuvaileva finiittimuotoinen verbi kuvailevat yhdessä subjektitarkoitetta. Pohjoissaamen koloratiivikonstruktio on seriaaliverbimäinen rakenne, jossa verbiparin kummatkin jäsenet ovat merkitykseltään yhtä painavia ja syntaktisesti tasavertaisia finiittiverbejä. Tarkastelin ensin suomen ja saamen koloratiivikonstruktion pääverbejä ja koloratiiviverbejä erikseen ja sen jälkeen molempia verbejä yhdessä.

Tutkimusmateriaalina on kaunokirjallisuus, joka sisältää saamen ja suomen kielestä kahdeksantoista eri kirjoittajan tekstejä, joka on ilmestynyt vuosina 1979-1997. Suomen kielessä koloratiivikonstruktiota esiintyy tietyissä murteissa ja erityisesti joidenkin kirjailijoiden teksteissä. Suomen kielen tutkijoiden apuna on myös suomen murteiden arkisto, jota saamen tutkija voi vain kadehtia. Kun suomen kielessä on tutkimuskohteena koloratiivirakenne, tutkija osaa suunnistaa mahdollisia tutkimusaineistoja kohti, koska rakennetta löytyy esim. tiettyjen kirjailijoiden teksteissä. Näyttää siltä, koloratiivikonstruktio ei ole kovin yleinen ilmiö saamenkielisessä kirjallisuudessa. Kävin läpi noin 2040 sivua, kahdeksaltatoista kirjoittajalta, ja löysin yksitoista koloratiivirakennetta. Esimerkkilauseet jakaantuvat neljän eri kirjailijan kesken, ja niistä suurin osa eli kahdeksan koloratiivirakennetta löytyy yhden kirjoittajan tekstistä. Ne liittyvät yhden kirjan aihepiiriin, joka kertoo lohestuksesta. Ei ole siis yllätys, että yleisin pääverbi on perus- 
merkitykseltään 'sauvoa', gorknodii stužai 'sauvoi loiski (ylävirtaan)'; goarkyui skolkkii 'sauvoi kaahasi kolisteli'; hoigadedje šávahedje 'sauvoa kaahasivat kohistivat'.

Suomen koloratiivirakenteen pääverbit ovat johtamattomia usein kaksitavuisia perusverbejä, jotka ilmaisevat jonkin elollisen toimijan olemista, tekemistä tai liikkumista. Saamen pääverbin tehtävä on aivan vastaavanlainen. Saamenkielisessä aineistossani ei erotu yhtään verbiä tai verbiryhmää, joka esiintyisi useammin kuin muut ja olisi jotenkin tyypillinen koloratiivirakenteelle. Pääverbi voi olla kaksi- tai useampitavuinen ja muodoltaan verbijohdos aivan yhtä hyvin kuin verbin johtamaton muoto. Pohjoissaamen verbijohdos on esim. subitiiviverbi (čálistit 'kirjoittaa nopeasti'), subitiivi-deminutiiviverbi (vázzilit 'kävellä lyhyt matka'), inkoatiiviverbi (suhkalit 'lähteä soutamaan') tai kontinuatiiviverbi (gorkyodit'sauvoa (ylävirtaan) hitaasti').

Suomen koloratiivikonstruktion jälkimmäinen verbi, koloratiiviverbi, on usein murteenmukainen verbi, jonka merkitys jää murretta taitamattomalle hämäräksi ilman pääverbiä. Saamen koloratiiviverbit ovat myös ilman pääverbejä ymmärrettäviä perusverbejä, jos kriteerinä pidetään sitä, että ne löytyvät pohjoissaamen sanakirjoista. Joissakin tapauksissa myös suomen koloratiiviverbit ovat yleiskielisiä perusverbejä, jotka saavat perusmerkityksestään poikkeavan merkityksen koloratiivirakenteen osana, esim. ampua poksauttaa, katsoa napittaa.

Suomen koloratiiviverbi on useimmiten kolmi- tai useampitavuinen ekspressiiviverbi, joka voi olla sen lisäksi johdos. Saamen kielessä verbin ekspressiivisyys tulee yksistään verbin perusmerkityksestä ja/tai johtimen lisäämisellä. Saamenkielisen aineiston perusteella ei ole nähtävissä tendenssiä kolmi- tai useampitavuisten koloratiiviverbien suosintaan. Saamenkielisessä aineistossa on kaksitavuisia koloratiiviverbejä saman verran kuin kolmitavuisiakin. Kun tarkastelee koloratiivirakenteen verbejä yhdessä, suomessa pääverbi on tavumäärältään lyhempi kuin koloratiiviverbi, usein siitä syystä, että edellinen on perusverbi ja jälkimmäinen on johdos. Saamen kielessä ei voi havaita samansuuntaista ilmiötä kuin suomessa, joten sekä pääverbi että koloratiiviverbi voivat 
olla kaksitavuisia verbejä. Saamessa pääverbi voi olla jopa tavumäärältään pitempi kuin koloratiiviverbi.

Kun tarkastelee saamen pääverbiä ja koloratiiviverbiä, on huomionarvoista se, että verbit ovat usein taivutustyypiltään yhteneväiset (veall-át gurg-át 'maata jonossa pitkin pituuttaan'; hoig-at šávv-at 'sauvoa kohista') tai merkitykseltään samanlaisia verbijohdoksia, esim. inkoatiiviverbejä (suhkalii jullagođii 'alkoi soutaa rytistellä'; suhkalit jullagoahtit 'alkaa soutaa, alkaa mekastaa'). Koloratiiviverbinä voi olla luonnon ääntä ilmaiseva verbi, vaikka kuvaillaan ihmisen liikkumisen tapaa. Suomen koloratiivikonstruktio muodostetaan neutraalista pääverbistä ja ekspressiivisestä koloratiiviverbistä, mutta pohjoissaamen koloratiivirakenteen kumpaakin verbiä voi kuvailla myös sanalla neutraali.

\section{Lyhenteet}

$\begin{array}{ll}1 & \text { 1. persoona } \\ 2 & \text { 2. persoona } \\ 3 & \text { 3. persoona } \\ \text { INF } & \text { perusinfinitiivi, A-infinitiivi, 1. infinitiivin lyhyempi muoto } \\ \text { PAST } & \text { preteriti } \\ \text { PL } & \text { monikko } \\ \text { PRES } & \text { preesens } \\ \text { S } & \text { subjekti } \\ \text { SG } & \text { yksikkö }\end{array}$

\section{Lähteet}

Bergsland, Knut 1961. Samisk grammatikk med øvelsesstykker. Kirke- og undervisningsdepartementet.

Gardemeister, Riikka-Maija 2005. Sataa tihmoi. 'A drizzling rain was coming down. Julkaisematon pro gradu -tutkielma. Joensuun yliopisto.

Hakulinen, Auli, Fred Karlsson 1979. Nykysuomen lauseoppia. Suomalaisen Kirjallisuuden Seuran toimituksia 350. Helsinki: Suomalaisen Kirjallisuuden Seura. 
Hamunen, Markus 2007. "Mee sai juosta lirputtaa”: koloratiivirakenne konstruktiona ja kieliopillistumana. Julkaisematon pro gradu -tukielma. Helsingin yliopisto.

Havo, Kirsi 1966. Verbaaliset koloratiivirakenteet Pentti Haanpään tuotannossa. Julkaisematon laudaturtyö. Helsingin yliopisto.

Heikkinen, Vesa, Eero Voutilainen 2009. Koloratiivirakenne Hirventappopaikkaromaanissa. - Vesa Heikkinen (Toim.). Kielen piirteet ja tekstilajit. Vaikuttavia valintoja tekstistä toiseen. Tietolipas 229. Helsinki: Suomalaisen Kirjallisuuden Seura, 135-169.

Jarva, Vesa 2008. Suomen kielen ekspressiivisten sanojen ominaispiirteitä. Keresztes László, Petteri Laihonen, Maticsák Sándor (Toim.). Folia Uralica Debreceniensia 15. Debrecen, 13-33.

Jarva, Vesa, Samu Kytölä 2007. The Finnish Colorative Construction and Expressivity. - SKY Journal of Linguistics 20, 235-272.

Iisa, Pekka 1965. Verbaalisen koloratiivikonstruktion käytöstä F. E. Sillanpään tuotannossa. Julkaisematon laudaturtyö. Helsingin yliopisto.

ISK 2004 = Hakulinen, Auli, MariaVilkuna, Riitta Korhonen, Vesa Koivisto, Tarja Riitta Heinonen, Irja Alho 2004. Iso suomen kielioppi. Suomalaisen Kirjallisuuden Seuran toimituksia 950. Helsinki: Suomalaisen Kirjallisuuden Seura.

Koistinen, Merja 2001. Koloratiivikonstruktiosta suomalaisessa kielentutkimuksessa. - Tõnu Seilenthal, Anu Nurk, Triinu Palo (Red.). Congressus nonus internationalis fenno-ugristarum 7.-13.8. 2000 Tartu. Pars V, Dissertationes sectionum: Linguistica II. Tartu, 101-105.

Korhonen, Leena 1967. Koloratiivirakenne Joel Lehtosen tuotannossa. Julkaisematon laudaturtyö. Helsingin yliopisto.

Luttinen, Saara 2000. Verbaaliset koloratiivikonstruktiot eräissä pohjoissavolaisissa murteissa. Pro gradu -työ. Jyväskylän yliopisto.

Mikone, Eve 2002. Deskriptiiviset sanat. Määritelmät, muoto ja merkitys. Helsinki: Suomalaisen Kirjallisuuden Seura.

MOT = Kielitoimiston sanakirja 2.0. http://mot.kielikone.fi/mot/OUYO/netmot. exe (18.2.2011).

Nickel, Klaus Peter 1994. Samisk grammatikk. Rievdaduvvon 2. deaddileapmi. Davvi girji o.s.

Nielsen, Konrad 1979 [1926-29]. Lærebok i lappisk (samisk) I Grammatikk. 2. opplag. Grammatikk, tekster og glosser. Bind I. Oslo: Universitetsforlaget. 
Ojutkangas, Krista 1998. Asyndeettisistä verbi-ilmaisuista suomalais-ugrilaisissa kielissä. - Anneli Pajunen (Toim.). Kieliopillistumisesta, analogiasta ja typologiasta. Helsinki: Suomalaisen Kirjallisuuden Seura, 110-143.

Penttilä, Aarni 2002. Suomen kielioppi. Kolmas muuttamaton painos. Marikki Penttilä (Toim.), Jari Palomäki (Johdanto). Vantaa: Dark Oy.

Rytkönen, Ahti 1937. Koloratiivinen konstruktio. - Virittäjä 41, 95-104.

Rääpysjärvi, Teija 2005. Näkökulmia verbaaliseen koloratiivikonstruktioon. Julkaisematon pro gradu -tukielma. Oulun yliopisto.

Saamelaiskäräjät 2010. http://www.samediggi.fi/index.php?option=com content \&task=view\&id=74\&Itemid=104 (2.2.2011).

Sammallahti, Pekka 1989. Sámi-suoma sátnegirji. Ohcejohka: Jorgaleaddji Oy.

Sammallahti, Pekka 1993. Sámi-suoma-sámi sátnegirji. Ohcejohka: Girjegiisá Oy.

Sammallahti, Pekka 1998. The Saami Languages. An Introduction. Kárášjohka: Davvi Girji OS.

Sammallahti, Pekka 2000. Cealkkaoahpa vuođđogursa, logaldatmánggus. Oulu: Oulu universitehta.

Saukkonen, Pauli 1966. Itämerensuomalaisten kielten tulosijainfinitiivirakenteiden historiaa II. Suomalais-ugrilaisen seuran toimituksia 140. Helsinki: Suomalais-ugrilaisen seura.

Setälä, E. N. 1987 [1880]. Suomen kielen lauseoppi. Oppikirjan koe. - Kalevi Wiik (Toim.). Suomen vanhat kieliopit. Nide 8. Turku: Turun yliopisto, fonetiikka, 1-54.

Sivula, Jaakko 1989. Deskriptiiviset sanat. - Jouko Vesikansa (Toim.). Nykysuomen sanavarat. Helsinki: WSOY, 165-182.

SSS = Suuri sivistyssanakirja 2000. Veli Valpola (Toim.). Helsinki: WSOY.

USS = Uusi sivistyssanakirja 1990. Annukka Aikio (Toim.), Rauni Vornanen (Uusinut). Helsinki: Otava.

Vest, Jovnna-Ánde 1995. Synonymasátnegirji. Lappi leanaráđđehus. 


\section{Liite 1. Saamenkielinen tutkimusaineisto}

Bongo, Mikkel P. A. 1985. Mus ledje bálgat, muitalusat. Deatnu: Jår'galæd’dji Å/S.

Einejord, Magne 1986. Ráimmahallan. Kárášjohka: Jår'galæd’dji Å/S.

Eira, Anders O. 1991. Duottarráfis soahtešilljui, muitalusat. Kárášjohka: Davvi Girji o.s.

Gaski, Harald 1990. Guhkkin nuppi bealdi ábi. Kárášjohka: Davvi Girji.

Guttorm, Eino 1985. Varahuvvan bálgát. Kárášjohka: Jår'galæd’dji Å/S.

Guttorm, Hans Aslak 1982. Golgadeamen. Deatnu: Jår'galæd'dji Å/S.

Guttorm, Johannes 1986. Heillodeaddji čázit. Deatnu: Jår'galæd’dji Å/S.

Huuva-Utsi, Inger 1987. Máddariid árbi, muitalusat. Svenska Samernas Riksförbund. Sápmi 5. Jokkmokk: Sámi Girjjit.

Jalvi, Pedar 1992. Okta eanehis eallingeardi ee. - Harald Gaski (doim.). Sátnedáidu. Goalmmát preanta. Kárášjohka: Davvi Girji o.s, 23-36.

Larsen, Anders 1992. Beaiveálgu. - Harald Gaski (doim.). Sátnedáidu. Goalmmát preanta. Kárášjohka: Davvi Girji o.s, 40-46.

Lukkari, Eino 1979. Bás Galle ja eara muitalusat. Helsset: Davviriikkaid sámiráđđi.

Paadar, Iisakki 1995. Issá muitala. Sámi Cuvgehussearvi / Lapin sivistysseuran julkaisuja 50. Helsinki: Sámi čuvgehussearvi.

Paadar-Leivo, Rauna 1994. Goalsenjárga: romána. Kárášjohka: Davvi Girji o.s.

Paltto, Kirsti 1989. Guovtteoaivvat nisu, noveallat. Ohcejohka: Gielas.

Paltto, Olavi 1995. Juohkásan várri, noveallat. Kárášjohka: Davvi Girji o.s.

Tapio, Ingrid 1997. Riesasilki, noveallat. Kárášjohka: Davvi Girji o.s.

Vars, Ellen Marie1996. Ja idja ii galgga šat leat. Álaheadju: De tre ans.

Vest, Joavnna-Ánde 1988. Čáhcegáddái nohká boazobálggis. Kárášjohka: Davvi Media o.s. 


\section{Liite 2. Suomenkielinen tutkimusaineisto}

Hassinen, Pirjo 1994. Ennustaja. Helsinki: Otava.

Hietamies, Heikki 1989. Sotapoika. Parasta kotimaista. Helsinki: Otava.

Huovi, Hannele 1992. Matka Grönlannin halki, novelleja. Helsinki: Tammi.

Jalonen, Olli 1990. Isäksi ja tyttäreksi. Toinen painos. Helsinki: Otava.

Joenpelto, Eeva 1991. Avoin, hellä ja katumaton. Porvoo: WSOY.

Joenpolvi, Martti 1988. Pronssikausi, novelleja. Jyväskylä: Gummerus.

Joensuu, Matti Yrjänä 1994 [1993]. Harjunpää ja rakkauden nälkä. Helsinki: Suuri suomalainen kirjakerho.

Kaipainen, Anu 1987. Vilulinnut. Porvoo: WSOY.

Kilpi, Eeva 1990 [1989]. Talvisodan aika, lapsuusmuistelma. Neljäs painos. Porvoo: WSOY.

Mikkonen, Sari 1995. Naistenpyörä, novelleja. Porvoo: WSOY.

Onkeli, Kreetta 1999 [1996]. Ilonen talo. Viides painos. Porvoo: WSOY.

Paasilinna, Arto 1991 [1988]. Suloinen myrkynkeittäjä. Porvoo: WSOY.

Pimenoff, Veronica 1985. Loistava Helena. Neljäs painos. Helsinki: Tammi.

Saarikoski, Pentti 1980. Asiaa tai ei. Helsinki: Otava.

Salama, Hannu 1978. Kolme sukupolvea, novelleja. Helsinki: Otava.

Seppälä, Juha 1990. Hyppynaru. Porvoo: WSOY.

Tervo, Jari 1999 [1992]. Pohjan hovi. Kuudes painos. Porvoo: WSOY.

Tuuri, Antti 1980. Maailman kivisin paikka, novelleja. Helsinki: Otava.

\section{Marjatta Jomppanen}

Giellagas-instituutti PL 1000

$\mathrm{FI}-90014$ Oulun yliopisto, Finland

marjatta.jomppanen@oulu.fi 


\title{
Comparison of colorative constructions in Finnish and North Saami
}

\author{
MARJATTA JOMPPANEN \\ Giellagas Institute
}

This paper focuses on serial verbs, so-called the colorative constructions, in the Finnish and North Saami languages. These serial verbs consist of two two components. In Finnish an infinitive verb forms the head of the construction and a finite verb, dependent on the head, dramatizes or specifies the denotative meaning of the construction. In North Saami, both components are neutral finite verbs. The material for the study comes from North Saami and Finnish fiction that was published in 1979-1997: it comprises of texts from 18 authors in both languages. The study is qualitative and its main emphasis is on North Saami.

In the Finnish language, the head of a colorative construction, commonly consists of two syllables, whereas in the North Saami language, the verbs may consists of two or more syllables. The latter component of a colorative construction is usually found only in some Finnish dialects and it is very difficult to understand its meaning without the head of the construction. By contrast, the verbs used in North Saami to form colorative constructions are quite common ones and can be understood without any context.

It is noteworthy that in North Saami both verbs in a colorative construction conjugate in a similar manner (hoig-at šávv-at 'to punt making a fuss') or have similar meanings, for example, to begin something (suhkalii jullagodii 'began to row with routing (to begin to rout)'). In North Saami, colorative verbs describe voices of nature although a human being has caused them.

Keywords: contrastive linguistics; head of construction; colarative construction; expressive verb; colorative verb; serial verb; verb derivation; Finnish; North Saami 